\title{
KAJIAN MUTU LABU SIAM (Sechium edule) TEROLAH MINIMAL YANG DIKEMAS VAKUM SELAMA PENYIMPANAN
}

\author{
Study of The Quality of Vacuum Packed Minimally Processed Chayote (Sechium Edule) \\ During Storage
}

\author{
Esron H. Pinem ${ }^{1 *}$, Ireine A. Longdong ${ }^{2}$, Lady C. Ch. E. Lengkey ${ }^{2}$ \\ ${ }^{1}$ Mahasiswa Program Studi Teknik Pertanian. \\ ${ }^{2}$ Dosen Program Studi Teknik Pertanian. \\ Jurusan Teknologi Pertanian Fakultas Pertanian, Universitas Sam Ratulangi \\ Jl. Kampus UNSRAT Manado 95115.
}

*Email: esron.harrystopinem@gmail.com

\begin{abstract}
This study aims to analyze the deterioration of the quality of the chayote during storage using several packaging methods. The research method was carried out experimentally and the data were processed descriptively which consisted of three treatments, namely: vacuum packed, without vacuum, and open. Each treatment was carried out 3 (three) times with each weight of 250 grams. Research shows that minimally processed chayote which is vacuum packed and stored at a temperature range of $5^{\circ} \mathrm{C}$ $9.6^{\circ} \mathrm{C}$ can last for 12 days, experiencing a weight loss of $0.90 \%$. The color changed from Faded Yellow to Gray Yellow. The texture becomes soft with a hardness value of $8.80 \mathrm{~N}$. The water content changes from $91.98 \%$ to $94.70 \%$.

In conclusion, the storage life of vacuum packed minimally processed chayote could be prolonged up to 12 days at $5^{\circ} \mathrm{C}-9,6^{\circ} \mathrm{C}$, greyyellow in color, texture softened, and weight loss as much as $0.90 \%$.
\end{abstract}

Keywords: Chayote, minimally processed, vacuum packed.

\section{PENDAHULUAN}

Labu siam (Sechium edule) merupakan salah satu bahan pangan lokal yang memiliki nilai gizi yang baik bagi tubuh manusia. Labu siam memiliki kadar serat yang cukub baik yaitu 1,7 gram per 100 gram. pengolahan secara minimal dalam bentuk potongan segar menjadi alternatif yang dapat dilakukan untuk mempercepat dan mempermudah proses pengolahan, meningkatkan keamanan dan mutu, memperluas jangkauan distribusi, dan mengurangi limbah berupa sampah yang berpotensi mencemari lingkungan. Pengemasan vakum merupakan salah satu aplikasi teknologi pengemasan dengan menggunakan kantong plastik vakum (vacuum pack), mengeluarkan semua udara dari dalam kemasan, kemudian ditutup rapat sehingga tercipta kondisi tanpa oksigen dalam kemasan tersebut 
(Jay, 2000). Berdasarkan Penelitian Tawali et al (2004) buah - buahan dan sayur - sayuran memerlukan pendinginan yang relatif cepat untuk mempertahankan kualitasnya. Penggunaan suhu rendah merupakan cara efektif untuk memperpanjang masa simpan bahan segar. Suhu penyimpanan merupakan salah satu faktor yang menyebabkan terjadinya perubahan kekerasan dari buah dan sayur, apabila suhu penyimpanan terlalu tinggi dapat menyebabkan proses respirasi dan transpirasi berlangsung lebih cepat sehingga menyebabkan kandungan air dari buah dan sayur lebih cepat mengalami penurunan yang dapat mengakibatkan berkurangnya kesegaran buah. Suhu rendah sangat mempengaruhi perubahan nilai kekerasan buah. Semakin rendah suhu penyimpanan maka semakin lambat penurunan nilai kekerasan buah (Tajul et al, 2012).

Usaha - usaha yang dapat dilakukan untuk mempertahankan mutu sekaligus memperpanjang umur simpan produk yang terolah minimal Salah satu metode yang efektif untuk memperpanjang umur simpan produk pengolahan minimal adalah menggunakan pengemasan plastik secara vakum yang dikombinasikan dengan suhu rendah dapat menghambat respirasi, menunda pelunakan dan perubahan mutu lainnya. Pengemasan vakum merupakan salah satu aplikasi teknologi pengemasan dengan menggunakan kantong plastik vakum (vacuum pack).

Penelitian ini bertujuan untuk menganalisis penurunan mutu labu siam terolah minimal selama penyimpanan dengan beberapa metode pengemasan.

\section{METODE PENELITIAN}

\section{Alat dan Bahan}

Alat yang digunakan dalam penelitian ini adalah vacum sealer (Merek Kris), lemari pendingin, pisau, multi grate, timbangan digital, timbangan analitik, aplikasi color grab, oven, Thermo Hygrometer, dan Fruit Textur Analyzer.

Bahan yang digunakan dalam penelitian ini adalah labu siam (Sechium edule) yang dipanen di Kota Tomohon dengan umur panen 4 bulan, plastik vakum dengan ukuran 22 x $20 \mathrm{~cm}$ ketebalan 250 micron, wadah styrofoam, dan wadah baskom.

\section{Rancangan Penelitian}

Metode penelitian dilakukan secara eksperimen dan data diolah secara deskriptif yang terdiri dari tiga perlakuan, yaitu dikemas vakum, tanpa vakum, dan terbuka. Setiap perlakuan dilakukan sebanyak 3 (tiga) kali ulangan dengan masing - masing berat $250 \mathrm{~g}$.

\section{Prosedur Kerja}

Prosedur kerja penelitian ini yang dilakukan adalah pemanenan dimana labu siam siap panen dengan ciri - ciri padat, berwarna hijau terang, dan permukaannya cukup rata, Labu siam dipetik dan dimasukan kedalam karung kemudian dibawa ke Laboratorium pascapanen. Labu siam dibersihkan kemudian labu siam dipotong, kemudian ditimbang dengan berat $250 \mathrm{~g}$, kemudian labu siam dikemas berdasarkan perlakuan. Labu siam yang sudah dikemas diletakkan pada suhu ruang dan kedalam lemari pendingin, pengamatan dilakukan setiap tiga hari sekali selama lima kali pengamatan. Pengamatan yang meliputi suhu dan RH, perubahan berat, kenampakan warna, tekstur, kadar air.

\section{Pengamatan}

\section{Suhu dan Kelembaban Relatif}

Suhu dan kelembaban relatif ruang penyimpanan diukur dengan menggunakan Thermo Hygrometer.

\section{Berat Bahan Selama Penyimpanan}

Untuk mengukur perubahan berat digunakan persamaan sebagai berikut :

Perubahan Berat $(\%)=\frac{W_{0}-W_{1}}{W_{0}} \times \mathbf{1 0 0}$ 
Dimana :

$\mathrm{W}_{0}=$ Berat awal labu siam $(\mathrm{g})$

$\mathrm{W}_{1}=$ berat akhir labu siam $(\mathrm{g})$

\section{Kenampakan Warna}

Pengukuran warna dilakukan dengan menggunakan kamera digital yang selanjutnya diolah menggunakan aplikasi color grab versi 3.6.1, pengujian warna ini dilakukan setiap 3 hari sekali selama masa penyimpanan. pengukuran warna ditentukan dengan koordinat $\mathrm{L}^{*}, \mathrm{a}^{*}, \mathrm{~b}^{*}$. Notasi $L^{*}$ merupakan ukuran tingkat kecerahan (lightness) dengan nilai : 0 (Hitam) sampai 100 (Putih). Notasi a* : warna kromatik campuran merah - hijau dengan nilai $+a^{*}$ (positif) dari 0 sampai +80 untuk warna merah dan nilai $-\mathrm{a}^{*}$ (negatif) dari 0 sampai -80 untuk warna hijau. Notasi $b^{*}$ : warna kromatik campuran biru - kuning dengan nilai $+b^{*}$ (positif) dari 0 sampai +70 untuk warna kuning dan nilai $-b^{*}$ (negatif) dari 0 sampai -70 untuk warna biru (Suyatma, 2009).

\section{Tekstur}

Tekstur labu siam pada penelitian diukur menggunakan Fruit Texture Analyzer. Nilai kekerasannya ditunjukkan dengan absolute (+) peak yaitu gaya maksimal dengan satuan parameter Newton $(\mathrm{N})$.

\section{Kadar Air}

Kadar air labu siam menggunakan oven. Kadar air dapat ditentukan dengan menggunakan persamaan:

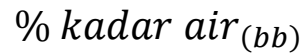

$$
\begin{aligned}
& =\frac{W-\left(W_{1}-W_{2}\right)}{W} \\
& \times 100
\end{aligned}
$$

Keterangan :

$\mathrm{W}=$ bobot sampel sebelum pemanasan $(\mathrm{g})$

$\mathrm{W}_{1}=$ bobot sampel setelah pemanasan $(\mathrm{g})$

$\mathrm{W}_{2}=$ bobot cawan kosong $(\mathrm{g})$

\section{HASIL DAN PEMBAHASAN}

\section{Suhu dan Kelembaban Relatif}

Suhu optimal labu siam yang terolah minimal secara umum tidak ada, Tetapi penelitian terhadap penyimpanan buah dan sayuran terolah minimal telah banyak dilakukan diantaranya untuk penyimpanan beberapa sayuran seperti berikut, Maryanti (2007) merekomendasikan penyimpanan sayuran campuran terolah minimal yang berisi kubis, kacang panjang, dan ketimun pada suhu $5^{\circ} \mathrm{C}$ selama 6 hari.

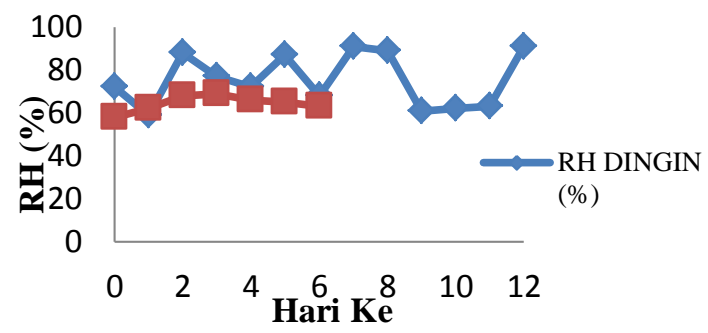

Gambar 1. Rata-rata suhu lemari pendingin dan suhu ruangan selama penyimpanan.

Dari Gambar 1 dapat dilihat bahwa penurunan suhu lemari pendingin yang signifikan terjadai pada hari ke 10 sampai hari ke 12 masing - masing $5,1^{\circ} \mathrm{C}, 5^{\circ} \mathrm{C}$, dan $5,2^{\circ} \mathrm{C}$ hal ini diakibatkan semangkin berkurangnya bahan yang disimpan didalam lemari pendingin, Sedangkan untuk kenaikan suhu lemari pendingin hanya terjadi pada hari ke 9 sebesar $9,6^{\circ} \mathrm{C}$. Sedangkan untuk suhu ruangan kenaikan maupun penurunan suhu tidak begitu jauh selama penyimpanan yang mengakibatkan bahan cepat rusak. Kenaikan suhu tertinggi terjadi pada hari ke 2 dan hari ke 5 yaitu sebesar $30,8^{\circ} \mathrm{C}$

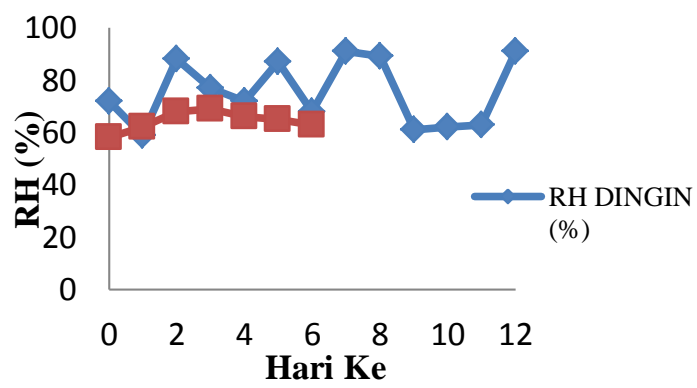

Gambar 2. Rata - rata kelembaban udara pada lemari pendingin dan suhu ruangan selama penyimpanan. 
Dari data kelembaban relatif suhu lemari pendingin dan suhu ruangan terlihat bahwa data pada kelembaban suhu lemari pendingin terendah didapat yaitu $59 \%$ dan kelembaban teringgi $91 \%$ dan pada kelembaban suhu ruangan yang terendah didapat yaitu $58 \%$ dan kelembaban tertinggi yaitu $69 \%$.

\section{Berat Bahan Selama Penyimpanan}

Dari Tabel 1 terlihat bahwa pada semua taraf suhu penyimpanan, perlakuan kemasan tebuka menunjukkan persentase perubahan berat paling tinggi dan berbeda nyata dengan kemasan lainnya, kemudian diikuti oleh kemasan tanpa vakum. Pada kemasan vakum menunjukkan persentase perubahan berat paling kecil dari antara lainnya. Hal ini menunjukkan bahwa pembungkus dapat menghambat laju transpirasi

$$
\text { Pada kemasan vakum }
$$

penyimpanan suhu dingin $7,30^{\circ} \mathrm{C}$ menunjukkan persentase perubahan berat paling kecil sebesar 0,90 \%, sedangkan pada kemasan terbuka penyimpanan ruang suhu $30,40^{\circ} \mathrm{C}$ menunjukkan persentase perubahan berat paling tinggi sebesar $60,66 \%$. Hal ini disebabkan karena pada suhu tinggi terjadi perbedaan tekanan uap antara bahan dengan udara sehingga penguapan cepat terjadi, dan membuat berat bahan menyusut (Takaendengan, 2016).

\section{Kenampakan Warna}

Secara visual perubahan warna labu siam ditunjukkan oleh berubahnya warna kuning kecoklatan yang ditandai dengan munculnya bintik - bintik hitam yang semakin lama semakin meluas. Hal ini diakibatkan karena adanya kematian sel sebagai akibat proses metabolisme yang terus terjadi selama penyimpanan (Musaddad, et al 2013).

Kenampakan warna labu siam pada suhu dingin $7,30^{\circ} \mathrm{C}$ labu siam yang dikemas secara vakum pada hari ke 0 didapat nilai $\left(\mathrm{L}^{*}\right)$ sebesar $67,40 \%$, nilai (a*) sebesar $-5,63 \%$, dan nilai $\left(b^{*}\right)$ sebesar $20,96 \%$ dengan warna faded yellow, pada kemasan tanpa vakum didapat nilai ( $\mathrm{L}^{*}$ ) sebesar 67,96\%, nilai (a*) sebesar $-6,53 \%$, dan nila ( $\left.b^{*}\right)$ sebesar $20,44 \%$ dengan warna green, dan pada kemasan terbuka didapat nilai $\left(\mathrm{L}^{*}\right)$ sebesar $68,40 \%$, nilai (a*) sebesar $-5,76 \%$, dan nilai (b*) sebesar $24,88 \%$ dengan warna yellow green.

Tabel 1. Persentase Perubahan Berat Labu Siam Selama Penyimpanan.

\begin{tabular}{|c|c|c|c|c|}
\hline Perlakuan & Berat Awal (g) & Berat Akhir (g) & $\begin{array}{c}\text { Persentase Perubahan } \\
\text { Berat (\%) }\end{array}$ & $\begin{array}{c}\text { Rata - rata } \\
\text { Persentase } \\
\text { Perubahan } \\
\text { Berat (\%) }\end{array}$ \\
\hline
\end{tabular}

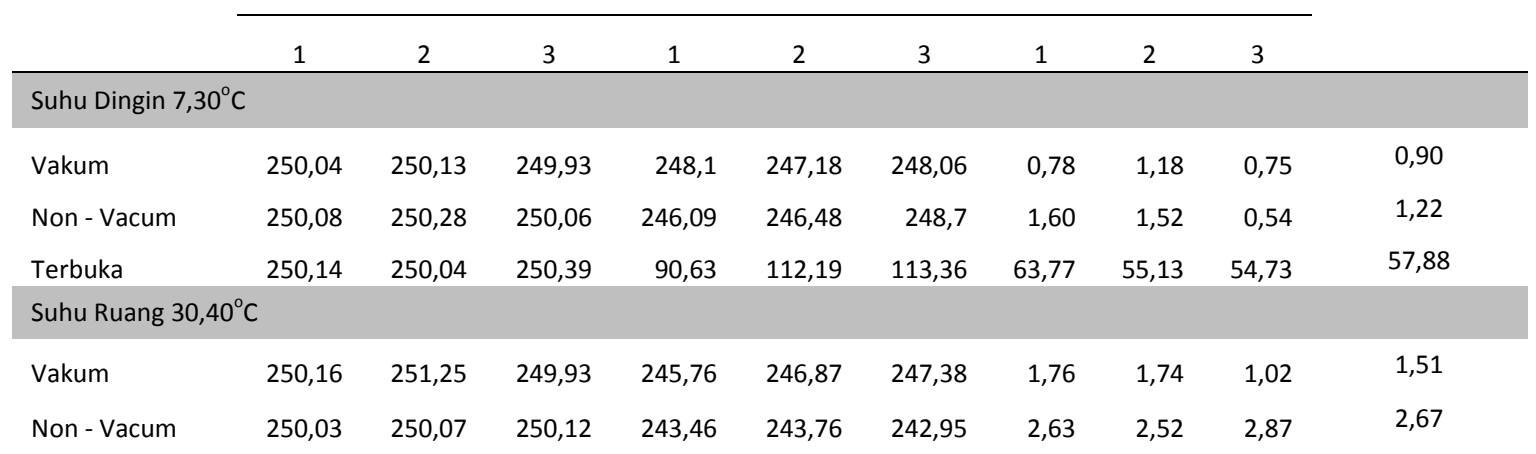


$\begin{array}{cccc}250,55 & 250,49 & 250,71 & 94,41 \\ \text { Kenampakan } & \text { warna } & \text { labu } & \text { siam }\end{array}$

setelah penyimpanan pada pengamatan hari ke 12 memberikan hasil yang berbeda pada kemasan vakum memiliki nilai $\left(\mathrm{L}^{*}\right)$ sebesar $67,60 \%$, nilai (a*) sebesar $-2,90 \%$, dan nilai $\left(b^{*}\right)$ sebesar $14,84 \%$ dengan warna grey yellow, pada kemasan tanpa vakum didapat nilai (L*) sebesar 65,31\%, nilai $\left(a^{*}\right)$ sebesar $-3,31 \%$, nilai $\left(b^{*}\right)$ sebesar $18,38 \%$ dengan warna faded yellow, dan pada kemasan tebuka didapat nilai $\left(\mathrm{L}^{*}\right)$ sebesar $65,90 \%$, nilai $\left(\mathrm{a}^{*}\right)$ sebesar $-2,43 \%$, nilai $\left(b^{*}\right)$ sebesar $16,50 \%$ dengan warna faded yellow.

Kenampakan warna labu siam pada suhu ruang $30,40^{\circ} \mathrm{C}$ hari ke 0 pada kemasan vakum didapat nilai $\left(\mathrm{L}^{*}\right)$ sebesar $69,19 \%$, nilai $\left(a^{*}\right)$ sebesar $-6,54 \%$, nilai $\left(b^{*}\right)$ sebesar $24,69 \%$ dengan warna yellow green , pada kemasan tanpa vakum didapat nilai ( L*) $^{*}$ sebesar $69,29 \%$, nilai (a*) sebesar $-6,17 \%$, nilai $\left(b^{*}\right)$ sebesar $23,74 \%$ dengan warna yellow green, dan pada kemasan terbuka didapat nilai $\left(\mathrm{L}^{*}\right)$ sebesar $69,18 \%$, nilai (a*) sebesar $-4,59 \%$, nilai $\left(b^{*}\right)$ sebesar $17,51 \%$ dengan warna faded yellow. Kenampakan warna setelah penyimpanan pada hari ke 6 memiliki hasil yang berbeda pada kemasan vakum memiliki nilai $\left(\mathrm{L}^{*}\right)$ sebesar $60,08 \%$, nilai $\left(a^{*}\right)$ sebesar $-3,33 \%$, nilai $\left(b^{*}\right)$ sebesar $16,20 \%$ dengan warna grey yellow, pada kemasan tanpa vakum didapat $\left(\mathrm{L}^{*}\right)$ sebesar 67,94\%, nilai (a*) sebesar $-4,03 \%$, nilai $\left(b^{*}\right)$ sebesar $17,18 \%$ dengan warna faded yellow, dan pada kemasan terbuka didapat nilai $\left(\mathrm{L}^{*}\right)$ sebesar $62,84 \%$, nilai (a*) sebesar $-3,14 \%$, dan nilai $\left(b^{*}\right)$ sebesar $23,39 \%$ dengan warna faded yellow.

\section{Tekstur}

Hasil penagamatan terhadap tekstur selama penyimpanan dapat dilihat pada Gambar 3. Pengukuran tekstur labu siam yang disimpan pada suhu dingin $7,30^{\circ} \mathrm{C}$ sebelum penyimpanan pada kemasan vakum yaitu $8,64 \mathrm{~N}$, pada kemasan tanpa vakum $9,61 \mathrm{~N}$, dan pada $\begin{array}{llllll}105,19 & 96,1 & 62,32 & 58,01 & 61,67 & 60,66\end{array}$ kemasan terbuka 9,09 N. Pengukuran tekstur labu siam setelah penyimpanan pada hari terakhir memberikan hasil yang berbeda pada tiga perlakuan yang digunakan. Pada kemasan vakum memiliki nilai yaitu $8,80 \mathrm{~N}$, pada kemasan tanpa vakum $8,43 \mathrm{~N}$, dan pada kemasan terbuka $8,61 \mathrm{~N}$.

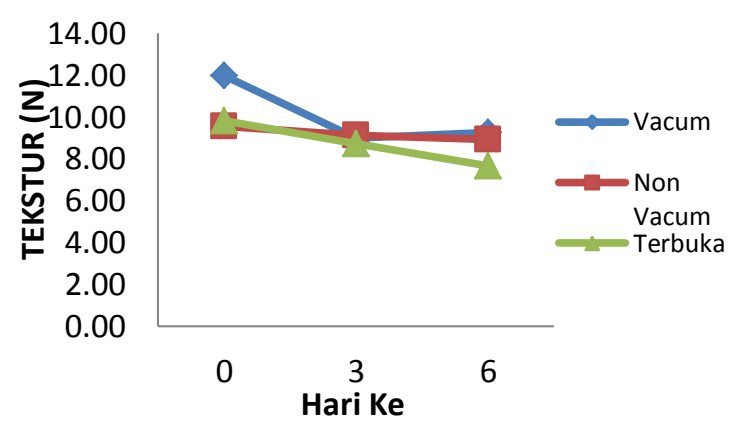

Gambar 3. Rata - rata nilai tekstur pada penyimpanan suhu dingin $7,30^{\circ} \mathrm{C}$.

Pengukuran tekstur pada labu siam yang disimpan pada suhu ruang $30,40^{\circ} \mathrm{C}$ sebelum penyimpanan pada kemasan vakum diperoleh nilai kekerasan yaitu $11,99 \mathrm{~N}$, pada kemasan tanpa vakum 9,56 $\mathrm{N}$, dan pada kemasan terbuka 9,80 N. Pengukuran tekstur setelah penyimpanan pada hari terakhir memiliki nilai kekerasan yang berbeda pada setiap kemasan yang digunakan. Pada kemasan vakum nilai kekerasan yang diperoleh 9,26 N, pada kemasan tanpa vakum 8,92 $\mathrm{N}$, dan pada kemasan terbuka 7,67 N.

Pengukuran tekstur pada labu siam yang disimpan pada suhu ruang $30,40^{\circ} \mathrm{C}$ sebelum penyimpanan pada kemasan vakum diperoleh nilai kekerasan yaitu $11,99 \mathrm{~N}$, pada kemasan tanpa vakum 9,56 $\mathrm{N}$, dan pada kemasan terbuka 9,80 N.

Pengukuran tekstur setelah penyimpanan pada hari terakhir memiliki nilai kekerasan yang berbeda pada setiap kemasan yang digunakan. Pada kemasan vakum nilai kekerasan yang diperoleh 
9,26 N, pada kemasan tanpa vakum 8,92 $\mathrm{N}$, dan pada kemasan terbuka 7,67 N.

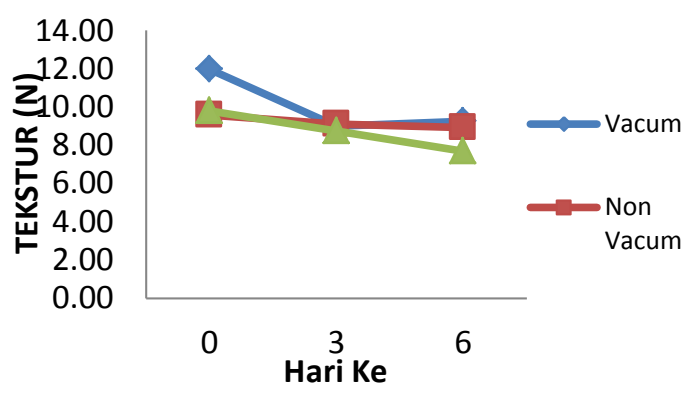

Gambar 4. Rata - rata nilai tekstur pada penyimpanan suhu ruang $30,40^{\circ} \mathrm{C}$.

Hal ini karena tidak adanya hambatan sirkulasi udara, sehingga dapat memicu terjadinya peningkatan transpirasi yang pada akhirnya dapat mempercepat pelunakan jaringan. Perubahan tekstur menjadi lebih lunak pada buah salah satunya dapat ditimbulkan oleh mekanisme kehilangan tekanan turgor, degradasi kandungan pati atau pemecahan dinding sel buah (Tucker et al, 1993).

\section{Kadar Air}

Untuk labu siam pada suhu dingin $7,30^{\circ} \mathrm{C}$ dengan kemasan vakum memperoleh kadar air dari 91,98\% menjadi $94,7 \%$, kemasan non vakum dari 91,39\% menjadi $95,6 \%$, dan kemasan terbuka dari $91,59 \%$ menjadi $87,44 \%$, sedangkan labu siam pada suhu ruang $30,40^{\circ} \mathrm{C}$ dengan kemasan vakum memperoleh kadar air dari 91,63\% menjadi 94,39\%, kemasan non vakum dari
91,9\% menjadi $95,03 \%$, dan kemasan terbuka dari $91,28 \%$ menjadi $84,29 \%$.

Hasil dari penelitian ini menunjukan bahwa adanya pengaruh interaksi nyata antara suhu penyimpanan dengan kemasan plastik terhadap laju perubahan kadar air labu siam selama penyimpanan. Pada semua taraf suhu penyimpanan, perlakuan tanpa kemasan menunjukkan terjadinya penurunan kadar air labu siam, sedangkan pada semua perlakuan kemasan dibungkus menunjukkan adanya peningkatan kadar air. Hal ini terjadi karena pada labu siam perlakuan terbuka tidak ada penghalang yang menyangga kontak bahan dengan udara bebas sehingga pergerakan udara disekitar bahan lebih cepat dan laju transpirasi berjalan lebih cepat. Pada labu siam yang dibungkus terdapat penghalang yang menyangga pergerakan uap air, sehingga udara dalam kemasan menjadi basah karena penambahan uap air bahan akibat adanya respirasi. Menurut Winarno (1989), proses hidrolisasi menghasilkan $\mathrm{CO}_{2}$ dan $\mathrm{H}_{2} \mathrm{O}$ sehingga dapat meningkatkan kandungan air. Hal ini sejalan dengan hasil penelitian Singh dan Sagar (2010) yang melaporkan bahwa sayuran daun yang dikemas mengalami peningkatan kadar air selam penyimpanan dan peningkatan pada suhu kamar relatif tinggi dibandingkan dengan suhu rendah.

Tabel 2. Persetase Kadar Air Awal dan Kadar Air Akhir Labu Siam.

\begin{tabular}{ccc}
\hline Perlakuan & Kadar Air Awal (\%) & Kadar Air Akhir (\%) \\
\hline Suhu Dingin $7,30^{\circ} \mathrm{C}$ & & 94,70 \\
Vacum & 91,98 & 95,60 \\
Tanpa Vacum & 91,39 & 87,44 \\
Terbuka & 91,59 & \\
Suhu Ruang $30,40^{\circ} \mathrm{C}$ & & 94,39 \\
Vacum & 91,63 & 95,03 \\
Tanpa Vacum & 91,90 &
\end{tabular}




Terbuka
KESIMPULAN
Labu siam terolah minimal yang
dikemas secara vakum dan disimpan pada
kisaran suhu $5^{\circ} \mathrm{C}-9,6^{\circ} \mathrm{C}$ dapat bertahan
selama 12 hari. Mengalami penurunan
berat sebesar 0,90\%. Warna berubah dari
Faded Yellow menjadi Grey Yellow.
Tekstur menjadi lunak dengan nilai
tekanan 8,80 N. Kadar air berubah dari
91,98\% menjadi $94,70 \%$.

\section{DAFTAR PUSTAKA}

Jay J.M. 2000. Modern Food Microbiology $6^{\text {th }}$ edition. Aspen

Publication: Guihenburg.

Maryanti, T. 2007. Teknik Pengemasan

Atmosfer Termodifikasi Untuk

Mempertahankan Mutu Sayuran

Campuran Terolah Minimal. Tesis.

Program Studi Teknologi

Pascapanen, Institut Pertanian

Bogor, Bogor.

Musaddad, D. 2013. Laju Perubahan Mutu Kubis Bunga Diolah Minimal pada Berbagai Kemasan dan Suhu Penyimpanan. Balai Penelitian Tanaman Sayuran. Lembang, Bandung Barat. Fakultas Teknologi Industri Pertanian UNPAD.

Singh, U dan V. R. Sagar. 2010. 'Quality characteristics of dehydrated leafy vegetables influenced by packaging materials and storage temperatur', J.Sci \& Ind. Res.., vol. 69,pp. 785-9.

Suyatma. 2009. Diagram Warna Hunter (Kajian Pustaka). Jurnal Penelitian Ilmiah Teknologi Pertanian, Institut Pertanian Bogor. Page 8-9.

Tajul. I. Sutrisno dan Titi.C.S, 2012 Pengaruh Kemasan Starch-Based Plastik (Bioplastik) Terhadap Mutu Tomat Dan Paprika Selama Penyimpanan Dingin.

Tawali A. B. 2004. Pengaruh Suhu Penyimpanan terhadap Mutu Buah- 